\title{
CONTRIBUTOS À TEORIA GERAL DO DIREITO PROCESSUAL COLETIVO ${ }^{1}$
}

\section{CONTRIBUTIONS TO THE GENERAL THEORY OF COLLECTIVE PROCEDURAL}

\section{$L A W$}

Rafael de Oliveira Costa

Visiting Scholar na Universidade da Califórnia-Berkeley. Professor Visitante na Wayne State University. Professor na Escola Superior do Ministério Público, no Programa de Mestrado da UNIFIEO e na UNIP. Doutor e Mestre em Direito pela Faculdade de Direito da UFMG. Promotor de Justiça no Estado de São Paulo. São Paulo/SP. E-mail: rafaelcosta22000@gmail.com.

\section{Pérsio Ricardo Perrella Scarabel}

Mestrando em Direito Penal pela Pontifícia Universidade Católica de São Paulo - PUCSP. Promotor de Justiça do Estado de São Paulo, ex-Promotor de Justiça do Estado de Mato Grosso do Sul. São Paulo/SP. E-mail: persioricps@yahoo.com.

RESUMO: O presente estudo atenta para a necessidade de unificação, em uma só disciplina, da abordagem epistemológica do Direito Processual Coletivo (Penal e Não Penal). A Ciência do Direito Processual Coletivo se desenvolveu sem que se buscasse a formação de uma estrutura uniforme de aplicação do Direito (epistemologia do Direito Processual Coletivo). Em que pese as peculiaridades de cada área do conhecimento, a unificação pode facilitar a compreensão dos institutos e exige a adoção de uma nova perspectiva, não mais limitada aos procedimentos civis, trabalhistas, eleitorais e administrativos coletivos, mas que abarque a esfera penal, permitindo uma coesão e coerência de caráter metodológico e científico,

\footnotetext{
${ }^{1}$ Artigo recebido em 26/11/2021 e aprovado em 09/12/2021.
} 
condensando princípios, regras e institutos penais e não penais em área do conhecimento que se convencionou chamar de Teoria Geral do Direito Processual Coletivo.

PALAVRAS-CHAVE: Unificação; Epistemologia do Direito Processual Coletivo; Teoria Geral do Direito Processual Coletivo; Classificação do Direito Processual Coletivo; Direito Processual Coletivo Penal e Não Penal.

ABSTRACT: The present study intends to unify, in a single discipline, the epistemological approach of Collective Procedural Law (Criminal and Non-Criminal). The Science of Collective Procedural Law has developed without a uniform structure for the application of Procedural Law (Epistemology of Collective Procedural Law). The unification requires, however, the adoption of a new perspective, which is no longer limited to collective civil, labor, electoral and administrative procedures. It should encompasses the criminal sphere, allowing a methodological and scientific cohesion and coherence, condensing principles and institutes in the area of knowledge that has been conventionally called the General Theory of Collective Procedural Law.

KEYWORDS: Unification; Epistemology of Collective Procedural Law; General Theory of Collective Procedural Law; Classification of Collective Procedural Law; Criminal and Non-Criminal Collective Procedural Law.

\section{INTRODUÇÃO}

Frankestein, obra literária das mais influentes, relata as mudanças que a criatura Frankestein - provoca em seu criador - o cientista. Igualmente, as criaturas imaginadas por promotores, advogados e juízes modificam as concepções de seus atores. Assim, a jurisprudência vem modificando a aplicação dos direitos coletivos, sua própria estrutura e seus criadores. Como a nossa referência a Frankestein sugere, a Teoria Geral do Direito Processual Coletivo propõe novos riscos e desafios para problemas ainda não resolvidos, em especial diante da abordagem - muitas vezes parcial - conferida pela doutrina à temática. 
Assim, o presente estudo pretende trazer contributos à Teoria Geral do Direito Processual Coletivo, ressaltando a necessidade de unificação, em uma só disciplina, da abordagem epistemológica do Direito Processual Coletivo (Penal e Não Penal).

Ora, a Ciência do Direito Processual Coletivo se desenvolveu sem que se buscasse a formação de uma estrutura uniforme de aplicação do Direito (epistemologia do Direito Processual Coletivo).

Contudo, a unificação da compreensão, além de seu potencial na adequada aplicação dos Direitos Coletivos, exige a adoção de uma nova perspectiva, não mais limitada aos procedimentos civis, trabalhistas, eleitorais e administrativos coletivos, mas que venha a abarcar a esfera penal, permitindo uma coesão e coerência de caráter metodológico e científico, condensando princípios, regras e institutos penais e não penais do Direito Processual Coletivo.

Passemos à concretização do nosso plano de estudos.

\section{BREVE ESCORÇO HISTÓRICO DA EVOLUÇÃO DA TUTELA COLETIVA}

Não há consenso na doutrina acerca da origem histórica da tutela coletiva. ${ }^{2}$

Em âmbito global, especialmente em países que adotam o sistema do civil law, parcela dos estudiosos sustenta que a tutela coletiva teve seu nascedouro com as actiones populares do Direito Romano. ${ }^{3}$ Embora inicialmente estivessem voltadas ao âmbito criminal - o que já demonstra a complementariedade que existe entre as diversas áreas do conhecimento relacionadas a feitos coletivos -, passaram a ser utilizadas também na tutela de pretensões coletivas não penais, especialmente no que concerne à defesa de "interesses de terceiros", tal como se dava com as ações pro libertate (defesa da liberdade) e ex lege Hostilia (defesa de bens de vítima de furto que estava ausente). ${ }^{4}$

De outro modo, parcela dos estudiosos aduz como nascedouro da tutela coletiva as cortes inglesas (sistema do common law), em razão da necessidade de prolação de decisões que viessem a atingir uma coletividade de jurisdicionados (compulsory joinder rule), nas

\footnotetext{
${ }^{2}$ Cf. NEVES, Daniel Amorim Assumpção. Manual de processo coletivo. 3. ed. Salvador: Ed. JusPodivm, 2016, p. 33-35.

${ }^{33}$ ALMEIDA, Gregório Assagra de. Direito Processual coletivo brasileiro. São Paulo: Saraiva, 2003, p. 41.

${ }^{4}$ LEONEL, Ricardo de Barros. Manual do processo coletivo. São Paulo: RT, 2002, p. 44-46.
} 
quais ocorria a formação de situação similar a de um "litisconsórcio multitudinário". ${ }^{5}$ Com o intuito de solucionar o problema, foi editado o Bill of Peace - diploma legal que regulamentava a matéria -, passando a admitir o ajuizamento das representative actions, ou seja, as primeiras demandas com a representação de uma coletividade por um ente. ${ }^{6}$

Acompanhando a evolução ocorrida no cenário mundial, no plano nacional podemos identificar três fases que refletem a evolução da tutela coletiva: ${ }^{7}$

1) fase da tutela individualista: predominou até 1934, inexistindo praticamente a tutela dos direitos ou interesses transindividuais no país;

2) fase da proteção incipiente dos direitos transindividuais: tem início com a Constituição de 1934, que em seu art. 113, n. 38, consagrou a Ação Popular $^{8}$ como ação coletiva destinada à tutela do patrimônio público da União, dos Estados ou dos Municípios. ${ }^{9}$ Posteriormente, a Lei n. 6.938, de 31 de agosto de 1981, consagrou ainda a responsabilidade ambiental objetiva, legitimando o Ministério Público para a propositura de ação com pedido reparatório por danos causados ao meio ambiente. Por fim, a Lei da Ação Pública, de 1985, incorporando ao ordenamento jurídico de forma definitiva a ideia de coletivização do processo, previa, inicialmente, o sistema da taxatividade da tutela jurisdicional coletiva, uma vez que o seu art. $1^{\circ}$ arrolava em rol exaustivo os direitos ou interesses transindividuais que poderiam ser objeto material da ação civil pública; ${ }^{10}$

3) fase da tutela jurídica ampla, integral ou irrestrita: teve início com a consagração pela Constituição de 1988, em seu art. 5, XXXV ("a lei não excluirá da apreciação do poder judiciário lesão ou ameaça a direito”), do princípio da inafastabilidade das decisões judiciais, seja para a tutela jurídica processual individual, seja para a tutela jurídica processual coletiva, incorporando a previsão da ação civil pública (art. 129, III, da CF), do

\footnotetext{
${ }^{5}$ LEAL, Márcio Flávio Mafra. Ações coletivas: história, teoria e prática. Porto Alegre: Sérgio Antônio Fabris Editor, 1998, p. 25.

${ }^{6}$ LEAL, Márcio Flávio Mafra. Ações coletivas: história, teoria e prática. Porto Alegre: Sérgio Antônio Fabris Editor, 1998, p. 25.

${ }^{7}$ Sobre o tema, conferir: CINTRA, Antonio Carlos de Araújo; GRINOVER, Ada Pellegrini; DINAMARCO, Cândido Rangel. Teoria geral do processo. 24a ed. São Paulo: Malheiros, 2008.

${ }^{8}$ MOREIRA, José Carlos Barbosa. A ação popular do direito brasileiro como instrumento de tutela jurisdicional dos chamados interesses difusos. Temas de Direito Processual Civil. São Paulo: Saraiva, 1977.

${ }^{9}$ Estabelecia referido dispositivo: "Qualquer cidadão será parte legítima para pleitear a declaração de nulidade ou annullação dos actos lesivos do patrimônio da União, dos Estados ou dos Municípios'.

${ }^{10}$ DIDIER JR., Fredie; BRAGA, Paula Sarno; OLIVEIRA, Rafael. Curso de Direito Processual Civil. $7^{\mathrm{a}}$ ed. Salvador: JusPodivm, 2007. v. 2. E ainda: GAJARDONI, Fernando da Fonseca. Direitos difusos e coletivos I. São Paulo: Saraiva, 2012. Também: MILARÉ, Edis. Ação Civil Pública - Lei 7.347/1985: reminiscência e reflexões após dez anos de aplicação. São Paulo, RT, 1995.
} 
mandado de segurança coletivo (art. $5^{\circ}$, LXIX e XX) e do mandado de injunção (art. $5^{\circ}$, LXXI, da CF). Nessa linha ainda, a Constituição de 1988 estabeleceu que o Ministério Público tem como função institucional a promoção do inquérito civil e da ação civil pública, a proteção do patrimônio público e social, do meio ambiente e de outros interesses coletivos (artigo 129, inciso III), ${ }^{11}$ implicando em verdadeira transformação do nosso ordenamento jurídico, passando do plano predominantemente individualista para o plano da tutela jurídica ampla, seja em relação aos direitos individuais, seja em relação aos direitos ou interesses coletivos. ${ }^{12}$

Devidamente traçado esse breve escorço histórico, passemos à delimitação da ideia de tutela coletiva penal e não penal.

\section{TUTELA COLETIVA PENAL E NÃO PENAL ${ }^{13}$}

O que é tutela coletiva? A expressão relaciona-se diretamente com o seu contraponto: a tutela individual.

Embora a jurisdição seja una, o gênero "tutela jurisdicional" compreende toda proteção conferida pelo Estado a um determinado direito material por meio do ajuizamento de um processo, tendo como intuito afastar a violação ou ameaça de violação a um bem jurídico. Esse gênero, em razão das diferentes formas de proteção, pode ter, dentre outras classificações, natureza inibitória ${ }^{14}$ ou ressarcitória, voluntária ou contenciosa.

Ademais, adotando-se como critério o direito material tutelado, a tutela jurisdicional pode ser classificada em individual ou coletiva. A tutela individual visa a proteger interesses

11 ANDRADE, Adriano; MASSON, Cleber; ANDRADE, Landolfo. Interesses difusos e coletivos esquematizado. São Paulo: Método, 2011.

12 Atualmente, muito se tem falado acerca de "processo estrutural", uma nova forma de se conceber o processo. O "processo estrutural" reflete uma nova sistemática processual, não mais restrita ao clássico princípio da demanda, que restringe a atuação do juiz aos pleitos deduzidos pelo autor. Os litígios vêm ganhando novas dimensões e o Direito Processual Coletivo precisa se adaptar a essa nova realidade. Assim, os efeitos da sentença passam a ser multilaterais, exigindo uma estrutura de tutela processual menos rígida, mais flexível, de modo a adaptar-se às necessidades do caso, normalmente relacionado à formulação e execução de políticas públicas (VITORELLI, Edilson. Levando os conceitos a sério: processo estrutural, processo coletivo, processo estratégico e suas diferenças. Revista de Processo, São Paulo, Ano 43, n. 284, p.333-369, out. 2018.).

13 A rigor, o presente trabalho deveria fazer referência à "tutela de direitos coletivos"; ocorre que a doutrina passou a utilizar a expressão para designar a "tutela de interesses coletivos", razão pela qual, evitando o preciosismo terminológico, preferimos adotar a expressão "tutela coletiva".

${ }^{14}$ Cf. ARENHART, Sérgio Cruz. Perfis da tutela inibitória coletiva. São Paulo: RT, 2003. 
ou direitos individuais, tendo como base o Código de Processo Civil e o Código de Processo Penal.

De outro modo, a tutela coletiva busca garantir proteção aos direitos coletivos em sentido amplo, compostos de três espécies distintas: os direitos difusos, os direitos coletivos em sentido estrito e os direitos individuais homogêneos.

Admite-se, ainda, a utilização da tutela coletiva para a defesa de direitos individuais, desde que tenham natureza indisponível, como sói ocorrer com a atuação do Ministério Público na defesa dos direitos de idosos, crianças, saúde pública, entre outros. ${ }^{15}$

Perceba-se, contudo, que estas duas últimas categorias - os direitos individuais homogêneos e os direitos indisponíveis - são passíveis de serem tutelados pela via individual, embora a tutela coletiva seja a via mais adequada para fazê-lo. De outro modo, a tutela coletiva afigura-se como o único meio cabível para o resguardo de direitos difusos e coletivos em sentido estrito, não sendo adequados os instrumentos disponibilizados para a tutela individual.

Partindo dessas premissas, a doutrina tem atentado para o microssistema ou minissistema ${ }^{16}$ de processo coletivo: trata-se de um conjunto de normas que, interpretadas de forma sistemática, regem as demandas coletivas. Apesar da existência de particularidades, o microssistema processual coletivo serve de base para a solução de todos os tipos de demandas coletivas, independentemente da espécie de direito tutelado (inclusive em direitos individuais homogêneos e indisponíveis), visto ser uma decorrência da exegese sistemática do art. 90, do $\mathrm{CDC}^{17}$, e art. 21, da LACP. ${ }^{18}$ Em verdade, "o processo coletivo é regulamentado de forma integrativa pelos dispositivos contidos no Código de Defesa do Consumidor, na Lei de Ação Civil Pública e no Código de Processo Civil"19.

Assim, o art. $8^{\circ}$, da LACP, que dispõe sobre o inquérito civil, incide, por exemplo, nas investigações relacionadas às relações de consumo. Trata-se, a bem dizer, de modalidade

\footnotetext{
${ }^{15}$ NEVES, Daniel Amorim Assumpção. Manual de processo coletivo. 3. ed. Salvador: Ed. JusPodivm, 2016, p. 38.

16 GRINOVER, Ada Pellegrini. Código Brasileiro de Defesa do Consumidor. 6 a ed. Rio de Janeiro: Forense Universitária, 1999, p. 33.

${ }^{17}$ Art. 90. Aplicam-se às ações previstas neste título as normas do Código de Processo Civil e da Lei $\mathrm{n}^{\circ}$ 7.347, de 24 de julho de 1985, inclusive no que respeita ao inquérito civil, naquilo que não contrariar suas disposições.

${ }^{18}$ Art. 21. Aplicam-se à defesa dos direitos e interesses difusos, coletivos e individuais, no que for cabível, os dispositivos do Título III da lei que instituiu o Código de Defesa do Consumidor.

${ }^{19}$ STJ, REsp 157838/ SP, Dl 19/10/1998, Rel. Min. Demócrito Reinaldo.
} 
de espécie jurisdicional diferenciada que confere uma nova roupagem a antigos institutos v.g., competência, legitimidade, coisa julgada, dentre outros. Por este motivo, a aplicação subsidiária da legislação processual civil não é ampla e ilimitada, sendo indispensável prévio exame de compatibilidade material e formal com a tutela coletiva. ${ }^{20}$

Desse modo, acabou-se tornando comum associar a tutela coletiva de direitos com a tutela de direitos coletivos. Contudo, enquanto no primeiro caso pode-se tutelar direitos individuais através, por exemplo, de um litisconsórcio ativo, figurando um grupo de autores na demanda, a tutela de direitos coletivos abrange apenas os direitos difusos, coletivos em sentido estrito e individuais homogêneos. ${ }^{21}{ }_{-}^{22}$

No entanto, parcela significativa da doutrina tem ignorado que o gênero tutela coletiva abrange duas espécies: a tutela coletiva não penal e a tutela coletiva penal. Esta última é objeto de estudo do Direito Processual Penal Coletivo, área do conhecimento responsável pelo adequado tratamento das questões afetas à processualística do Direito Penal em âmbito coletivo. Como já tivemos a oportunidade de assinalar, trata-se de um "conjunto de normas que regula a aplicação jurisdicional do Direito Penal Coletivo e que tem como finalidade precípua a busca pela pacificação social através do exercício do ius puniendi estatal," ${ }^{23}{ }^{24}$

Assim como ocorre com o processo coletivo não penal, a tutela coletiva penal visa assegurar o princípio da inafastabilidade da jurisdição no seu aspecto de acesso à ordem jurídica justa/adequada. Não por outro motivo tem-se admitido para a tutela coletiva todas as espécies de ações capazes de garantir direitos materiais, o que vale não apenas para a seara não penal, mas também para a penal. ${ }^{25}$

\footnotetext{
${ }^{20}$ Conforme ficará claro à frente, os princípios de interpretação e aplicação próprios do direito constitucional incidem não apenas no direito processual coletivo especial, mas também no processo coletivo comum.

${ }^{21}$ Cf. ZAVASCKI, Teori Albino. Processo Coletivo: Tutela de Direitos Coletivos e Tutela Coletiva de Direitos. São Paulo: Editora Revista dos Tribunais, 2006.

${ }^{22}$ MAZZILLI, Hugo Nigro. A defesa dos interesses difusos em juizo. 15ª ed. São Paulo: Saraiva, 2002.

${ }^{23}$ ALMEIDA; Gregório Assagra de. COSTA, Rafael de Oliveira. Direito processual penal coletivo - A Tutela Penal dos Bens Jurídicos Coletivos: Direitos ou Interesses Difusos, Coletivos e Individuais Homogêneos. Belo Horizonte: D’Plácido, 2019, p. 117.

${ }^{24}$ Sobre o tema, conferir também: COSTA, Rafael de Oliveira; MORAES, Alexandre Rocha Almeida de. O Processo Coletivo: primeiras impressões para a construção de uma nova dogmática processual. In: Revista Brasileira de Direito Processual Penal, v. 5, p. 1609 e seguintes, 2019.

${ }^{25}$ ALMEIDA; Gregório Assagra de. COSTA, Rafael de Oliveira. Direito processual penal coletivo - A Tutela Penal dos Bens Jurídicos Coletivos: Direitos ou Interesses Difusos, Coletivos e Individuais Homogêneos. Belo Horizonte: D’Plácido, 2019, p. 117.
} 
A pluralidade de diplomas processuais que regulamenta a tutela coletiva torna complexa a determinação de qual ou quais deles devem incidir na solução de um determinado caso concreto. De forma quase unânime, a doutrina sustenta que o microssistema é formado, principalmente, pela Constituição, pela Lei da Ação Civil Pública e pelo Código de Defesa do Consumidor, sem prejuízo da incidência de uma série de outros diplomas, tais como a Lei 4.717/1965 (Ação Popular), a Lei 6.938/1981 (Lei da Política Nacional do Meio Ambiente), a Lei 7.853/1989 (Lei das Pessoas Portadoras de Deficiência); a Lei 7.913/1989 (Lei dos Investidores dos Mercados de Valores Imobiliários), a Lei 8.069/1990 (Estatuto da Criança e do Adolescente), a Lei 8.429/1992 (Lei de Improbidade Administrativa), a Lei 10.741/2003 (Estatuto do Idoso), a Lei 12.016/2009 (Lei do Mandado de Segurança) e a Lei 13.300/2016 (Lei do Mandado de Injunção).

Contudo, essa perspectiva desconsidera o Direito Processual Penal Coletivo, levando em consideração exclusivamente as normas que regem as relações processuais coletivas no âmbito não penal. Uma concepção hodierna do microssistema deve abranger, além desses diplomas, o Código de Processo Penal e toda a legislação processual penal que busca tutelar bens jurídico-penais coletivos.

Partindo dessas premissas, passaremos no próximo tópico a analisar a forma como deve ser estruturada a Teoria Geral do Direito Processual Coletivo.

\section{DA TEORIA GERAL DO DIREITO PROCESSUAL COLETIVO}

A unificação, em uma só disciplina, dos estudos de Direito Processual Coletivo (Não Penal e Penal) é tarefa hercúlea. As esferas (Não Penal e Penal) se desenvolveram de forma independente e praticamente estanques, ou seja, sem que se buscasse um diálogo e a formação de uma estrutura uniforme de aplicação da tutela coletiva.

A sistematização em uma Teoria Geral do Direito Processual Coletivo exige uma nova forma de compreensão dos institutos, em especial porque a instrumental teórico, da forma como tem sido uniformizado até o momento, tem se mostrado algumas vezes inadequado para a defesa de direitos de elevada estatura constitucional, em especial diante do princípio da independência das instâncias. 
A Teoria Geral do Direito Processual Coletivo exige, simultaneamente, uma estrutura unificada e flexível, de modo a permitir não apenas uma congruência sistemática, mas também a versatilidade necessária para o diálogo com o Direito Material Coletivo (Penal e Não Penal). Além disso, deve ser vislumbrada enquanto disciplina jurídica com viés epistemológico, ramo da Filosofia do Direito Processual Coletivo, voltada à elaboração e à articulação de conceitos jurídicos fundamentais processuais coletivos. ${ }^{26}$ Trata-se, em verdade, de área do conhecimento que deve ocupar-se dos conceitos fundamentais relacionados à Ação Coletiva, Defesa Coletiva, Jurisdição Coletiva, Processo Coletivo e Coisa Julgada Coletiva.

Com efeito, a Teoria Geral do Direito Processual Coletivo só pode ser uma teoria geral se os conceitos jurídicos fundamentais (lógico-jurídicos) processuais que se pretende construir tiverem um viés universalizante. Não se pode, portanto, confundir a Teoria Geral do Direito Processual Coletivo com a ideia de um "Direito Processual Unificado" (Não Penal e Penal), visto que o produto da Filosofia do Direito Processual Coletivo (ou seja, a Teoria Geral do Direito Processual Coletivo) não é o conjunto ou a somatória de normas jurídicas processuais (ou seja, o Direito Processual Coletivo), mas resulta da sistematização de conceitos fundamentais e universais.

De qualquer modo, a Teoria Geral do Direito Processual Coletivo, em si mesma, deve ser vislumbrada sob uma perspectiva una: não é possível separar as ciências processual penal e não penal coletivas, por constituírem partes de um único saber. A Teoria Geral do Direito Processual Coletivo deve ser construída a partir de uma estrutura lógico-jurídica básica, compartilhada, fundada nos institutos jurídicos da ação coletiva, da jurisdição coletiva, da defesa coletiva, da coisa julgada coletiva e do processo coletivo.

Em verdade, a Teoria Geral do Direito Processual Coletivo deve permitir uma coesão e coerência de caráter metodológico e científico, condensando princípios, regras e institutos

\footnotetext{
${ }^{26}$ Sobre o tema: "A evolução doutrinária a respeito dos processos coletivos autoriza a elaboração de um verdadeiro Direito Processual Coletivo como ramo do direito processual, que tem seus próprios princípios e regras, diversos do direito processual individual. Os institutos da legitimação, competência, poderes e deveres do juiz e do Ministério Público, conexão, litispendência, liquidação e execução de sentença, coisa julgada, entre outros, têm feição própria nas ações coletivas que, por isso mesmo, se enquadram numa Teoria Geral dos Processos Coletivos. Diversas obras, no Brasil, já tratam do assunto. E o país, pioneiro no tratamento dos interesses e direitos transindividuais, por intermédio da LACP, tem toda a capacidade para elaborar um verdadeiro Código de Processos Coletivos, que mais uma vez o colocará numa posição de vanguarda." (GRINOVER, Ada Pellegrini. Rumo a um Código Brasileiro de Processos Coletivos. MAZZEI, Rodrigo e NOLASCO, Rita Dias (Coordenadores). Processo Civil Coletivo. São Paulo: Quartier Latin, 2005, p. 722-723).
} 
penais e não penais do Direito Processual Coletivo. Compõe-se de normas que determinam o modo como o Direito Processual Coletivo deve estruturar-se. Embora não exista uniformidade legislativa, o estudo da Teoria Geral do Direito Processual Coletivo deve ser fruto da autonomia científica alcançada pelo Direito Processual Coletivo e ter como enfoque o complexo de regras e princípios que regem o exercício da jurisdição coletiva. Vejamos:

\begin{abstract}
Em síntese, seria fundamental para essa empreitada teórica: a superação da concepção de pretensão em penal e civil (não penal), para elaborar também a ideia de pretensão coletiva; a superação do problema da legitimidade ad causam ativa, que tradicionalmente se biparte em ordinária e extraordinária, para a adoção de uma nova categoria, talvez em conformidade com o que Nelson Nery Junior denomina legitimação autônoma para a condução do processo; a superação da própria postura institucional do Poder Judiciário, que, de órgão técnico e formal, passaria a ser concebido como instância política de transformação positiva da realidade social; a superação da concepção dicotômica de direito processual em direito processual civil e direito processual penal, para consolidar a concepção tricotômica, com a inserção também do direito processual coletivo; a superação das concepções clássicas de interpretação e aplicação do direito processual, de forma a passar a adotar as regras principiológicas de interpretação constitucional. ${ }^{27}$
\end{abstract}

De forma didática, o Direito Processual Coletivo é a área do conhecimento que trata do conjunto de normas que cuidam do exercício da função jurisdicional coletiva. Situa-se, portanto, dentro da grande área do conhecimento "Direito Coletivo". E a Ciência do Direito Processual Coletivo (Ciência Dogmática do Direito Processual Coletivo ou, simplesmente, Ciência do Direito Processual Coletivo) pode ser entendida como o ramo do pensamento jurídico de caráter dogmático dedicado a formular os fundamentos e as diretrizes básicas para a aplicação do Direito Processual Coletivo. O Direito Processual Coletivo é o objeto desta Ciência, que tem como incumbência a elaboração e sistematização dos conceitos jurídico-positivos relacionados aos feitos coletivos. Temos, portanto, dois planos distintos: um normativo (Direito Processual Coletivo) e um doutrinário (Ciência do Direito Processual Coletivo).

Em assim sendo, a relação que se estabelece entre a Teoria Geral do Direito Processual Coletivo (de caráter epistemológico, que está ao lado da Sociologia do Direito Processual Coletivo, da História do Direito Processual Coletivo, dentre outras) e a Ciência

\footnotetext{
${ }^{27}$ ALMEIDA, Gregório Assagra de. Direito Processual Coletivo: um novo ramo do direito processual. São Paulo: Saraiva, 2003, p. 610/611.
} 
do Direito Processual Coletivo (de caráter dogmático) é a mesma que se estabelece entre a Teoria Geral do Processo e a Ciência do Direito Processual. Isso porque a Teoria Geral do Direito Processual Coletivo tem como objeto a Ciência do Direito Processual Coletivo (civil, penal, trabalhista, eleitoral e administrativo), e não o Direito Processual; não se ocupa do fazer das normas processuais, mas atua como epistemologia do Direito Processual Coletivo.

Quanto às normas de incidência, o Direito Processual Coletivo pode ser classificado como Internacional ou Interno. O Direito Interno, por sua vez, subdivide-se em duas grandes áreas: de um lado, o Direito Processual Penal Coletivo; de outro, o Direito Processual Coletivo Não Penal, que se subdivide em Direito Processual Civil Coletivo, Direito Processual Trabalhista Coletivo, Direito Processual Eleitoral Coletivo e Direito Processual Administrativo Coletivo.

Devidamente expostas essas premissas fundamentais, passemos à análise da classificação do Direito Processual Coletivo.

\section{DA CLASSIFICAÇÃO DO DIREITO PROCESSUAL COLETIVO}

Os processos coletivos são usualmente classificados em duas categorias: o os processos coletivos comuns e os processos coletivos especiais. Cada uma das espécies apresenta características próprias, que as distinguem da outra. A título de exemplo, o direito processual coletivo comum adota o princípio da disponibilidade motivada da ação coletiva, ao passo que no processo coletivo especial prevalece o princípio da indesistibilidade da ação.

Contudo, uma terceira espécie tem sido esquecida pela doutrina: o Direito Processual Penal Coletivo.

Por este motivo, acreditamos que a melhor classificação é aquela que permite distinguir as diferentes vertentes do Direito. Vejamos:

1) O Direito Processual Coletivo Comum, que se subdivide em:

a. Direito Processual Coletivo Comum Não Penal, abrangendo as esferas civil, trabalhista, eleitoral e administrativa;

b. Direito Processual Comum Penal; 
2) O Direito Processual Coletivo Especial, que se subdivide em:

a. Direito Processual Coletivo Especial Não Penal, abrangendo as esferas civil, trabalhista, eleitoral e administrativa;

b. Direito Processual Coletivo Especial Penal;

3) Processos pseudocoletivos;

4) Processos pseudoindividuais.

Assim, o processo coletivo comum não penal é caracterizado pela existência de um caso concreto a ser solucionado, ou seja, por um efetivo conflito de interesses ou uma ameaça de violação a um direito difuso, coletivo em sentido estrito, individual homogêneo ou individual indisponível. Admite, exemplificativamente, diferentes espécies de ações: 1) a ação popular; 2) a ação civil pública; 3) a ação de improbidade administrativa; 4) o mandado de segurança coletivo; e 5) o mandado de injunção coletivo. ${ }^{28}$

De outro modo, o processo coletivo comum penal é caracterizado pela violação in concreto de bens jurídico-penais de natureza coletiva em sentido amplo. Em outras palavras, não tutela bens jurídico-penais individuais ou a norma de forma abstrata, mas apenas casos nos quais tenha havido a violação concreta de bem jurídico-penal coletivo, v.g., meio ambiente, patrimônio público, entre outros. Admite-se, para tanto, a utilização de três espécies principais de ações: 1) a ação penal coletiva; 2) o mandado de segurança coletivo criminal; e 3) o habeas corpus coletivo. ${ }^{29}$

No que concerne ao processo coletivo especial, caracteriza-se pela ausência de solução de um conflito de interesses decorrente da violação ou ameaça de lesão a um direito difuso, mas cinge-se à análise da constitucionalidade de uma lei em tese. Em outras palavras, tutela a coerência e integridade constitucional do ordenamento jurídico (direito difuso), preservando-o de eventuais violações, sem resolver uma lide. Divide-se em processo

\footnotetext{
${ }^{28}$ Não se olvida que o nome conferido à demanda pouco importa, visto que a distinção das diferentes espécies ocorre realmente com os pedidos formulados. De qualquer modo, a distinção terminológica é relevante porque normalmente vem atrelada à natureza do direito material coletivo tutelado e às peculiaridades procedimentais de cada espécie de demanda.

${ }^{29}$ ALMEIDA; Gregório Assagra de. COSTA, Rafael de Oliveira. Direito processual penal coletivo - A Tutela Penal dos Bens Jurídicos Coletivos: Direitos ou Interesses Difusos, Coletivos e Individuais Homogêneos. Belo Horizonte: D’Plácido, 2019.
} 
coletivo especial não penal, quando tutela a integridade do ordenamento jurídico nas esferas civil, trabalhista, eleitoral e administrativa, e processo coletivo especial penal, quando analisa a constitucionalidade das normas sob égide criminal. A título de exemplo, pode-se mencionar a ação direta de inconstitucionalidade (ADI), a ação declaratória de constitucionalidade (ADC) e a ação de descumprimento de preceito fundamental.

É possível o controle de constitucionalidade no processo coletivo comum penal e não penal (v.g., ação civil pública ou ação penal coletiva)? Sim, é o conhecido controle difuso, aberto, de constitucionalidade. Ocorre que é dotado de uma particularidade: não pode ser utilizado como pedido principal da demanda - o que só pode ser pleiteado em sede de processo coletivo especial. ${ }^{30}$ Quando a declaração de inconstitucionalidade for o pedido da demanda, só poderá ser formulado por meio de processo coletivo especial; de outro modo, quando constar da causa de pedir, poderá ser formulado no processo coletivo comum (penal e não penal). ${ }^{31}$

No que concerne aos processos pseudocoletivos, trata-se de demandas que apresentam características típicas dos feitos coletivos, mas que tutelam direitos individuais. Não se confundem com a tutela de direitos individuais homogêneos e individuais indisponíveis, visto que os processos pseudocoletivos afastam por completo a incidência do microssistema coletivo. A título de exemplo, pode-se mencionar a execução coletiva da pretensão individual, prevista no art. 98, do CDC. Embora ajuizada por um dos entes previstos no art. 82, do CDC, a execução tem natureza individual, não tutelando os interesses da coletividade.

De outro modo, os processos pseudoindividuais são caracterizados pela formulação de pedido vinculado a uma pretensão individual, de natureza incindível, mas que resvala no interesse da coletividade. Em outras palavras, a procedência do pedido individual acaba gerando como "efeito" a defesa de direitos difusos ou coletivos - embora o indivíduo não tenha legitimidade ativa para fazê-lo. A título de exemplo, pode-se mencionar a pretensão de um determinado autor que vem atrelada simultaneamente a danos a direitos difusos ou coletivos, como acontece com a poluição causada por uma indústria que afeta a saúde de um proprietário de terreno próximo. ${ }^{32}$ Nesse caso, temos simultaneamente uma violação a direito

\footnotetext{
${ }^{30}$ STF. Plenário. Rcl 6.449 AgRg/RS, Rel. Eros Grau, julgado em 25.11.2009.

${ }^{31}$ STF. Plenário. ADI 3406/RJ e ADI 3470/RJ, Rel. Min. Rosa Weber, julgados em 29/11/2017.

${ }^{32}$ ALMEIDA, Gregório Assagra de. Direito Processual coletivo brasileiro. São Paulo: Saraiva, 2003, p. 496.
} 
Revista Eletrônica de Direito Processual - REDP.

Rio de Janeiro. Ano 16. Volume 23. Número 1. Janeiro a Abril de 2022

Periódico Quadrimestral da Pós-Graduação Stricto Sensu em Direito Processual da UERJ

Patrono: José Carlos Barbosa Moreira (in mem.). ISSN 1982-7636. pp. 1142-1159

www.redp.uerj.br

individual, coletivo em sentido estrito e difuso. Indiscutivelmente, a melhor solução seria ingressar com uma demanda coletiva, objetivando sanar a irregularidade para toda a sociedade. Contudo, como o proprietário não tem legitimidade para pleitear a tutela coletiva, ficaria a depender de um legitimado coletivo e, caso nenhum deles se dispusesse a ingressar com o feito, o indivíduo não poderia ser obrigado a suportar eventuais males causados à sua saúde. Assim, não permitir o ajuizamento de ação individual seria violar o princípio da inafastabilidade da jurisdição.

Pondere-se que, em sendo possível a tutela do direito individual sem que se venha a tutelar o direito difuso ou coletivo violado, óbice algum existe em resguardar o interesse do indivíduo. Assim, se o autor pleitear a condenação do réu apenas a indenizar os danos à sua saúde (direito individual), não há qualquer óbice ao acolhimento da pretensão. Contudo, em sendo indispensável a defesa do direito coletivo ou difuso - no nosso exemplo, através da paralisação das atividades da fábrica -, óbice algum existe ao acolhimento do pleito, afastando a continuidade da lesão ao direito da coletividade a um meio ambiente saudável. ${ }^{33}$

Por fim, diante de situações como a mencionada acima, em que pese o veto ao artigo 333, do CPC, que permitia a conversão da ação individual em ação coletiva ${ }^{34}$, entendemos

\footnotetext{
${ }^{33}$ NEVES, Daniel Amorim Assumpção. Manual de processo coletivo. 3. ed. Salvador: Ed. JusPodivm, 2016, p. 102.

${ }^{34} \mathrm{O}$ dispositivo original continha a seguinte redação: "Art. 333. Atendidos os pressupostos da relevância social e da dificuldade de formação do litisconsórcio, o juiz, a requerimento do Ministério Público ou da Defensoria Pública, ouvido o autor, poderá converter em coletiva a ação individual que veicule pedido que: I - tenha alcance coletivo, em razão da tutela de bem jurídico difuso ou coletivo, assim entendidos aqueles definidos pelo art. 81, parágrafo único, incisos I e II, da Lei no 8.078 , de 11 de setembro de 1990 (Código de Defesa do Consumidor), e cuja ofensa afete, a um só tempo, as esferas jurídicas do indivíduo e da coletividade; II - tenha por objetivo a solução de conflito de interesse relativo a uma mesma relação jurídica plurilateral, cuja solução, por sua natureza ou por disposição de lei, deva ser necessariamente uniforme, assegurando-se tratamento isonômico para todos os membros do grupo. § I Io Além do Ministério Público e da Defensoria Pública, podem requerer a conversão os legitimados referidos no art. 5o da Lei $n^{\circ}$ 7.347, de 24 de julho de 1985, e no art. 82 da Lei no 8.078, de 11 de setembro de 1990 (Código de Defesa do Consumidor). § $2^{\circ}$ A conversão não pode implicar a formação de processo coletivo para a tutela de direitos individuais homogêneos. § $3^{o}$ Não se admite a conversão, ainda, se: I - já iniciada, no processo individual, a audiência de instrução e julgamento; ou II - houver processo coletivo pendente com o mesmo objeto; ou III - o juízo não tiver competência para o processo coletivo que seria formado. $\$ 4^{\circ}$ Determinada a conversão, o juiz intimará o autor do requerimento para que, no prazo fixado, adite ou emende a petição inicial, para adaptá-la à tutela coletiva. § 5 - Havendo aditamento ou emenda da petição inicial, o juiz determinará a intimação do réu para, querendo, manifestar-se no prazo de 15 (quinze) dias. § 6o O autor originário da ação individual atuará na condição de litisconsorte unitário do legitimado para condução do processo coletivo. $\$ 70$ O autor originário não é responsável por nenhuma despesa processual decorrente da conversão do processo individual em coletivo. § $8^{o}$ Após a conversão, observar-se-ão as regras do processo coletivo. $\$ 9^{\circ}$ A conversão poderá ocorrer mesmo que o autor tenha cumulado pedido de natureza estritamente individual, hipótese em que o processamento desse pedido dar-se-á em autos apartados. \$10. O Ministério Público deverá ser ouvido sobre o requerimento previsto no caput, salvo quando ele próprio o houver formulado."
} 
que óbice algum existe à adoção da medida, em exegese analógica do art. $9^{\circ}$ da Lei $\mathrm{n}^{\circ}$ 13.300/2016, e em atenção ao princípio da máxima efetividade dos direitos coletivos. Ora, o art. $9^{\circ}$ da Lei do Mandado de Injunção admite expressamente a "coletivização dos efeitos da decisão" ao dispor que, além da possibilidade de ser conferida eficácia ultra partes ou erga omnes à decisão - quando isso for inerente ou indispensável ao exercício do direito, da liberdade ou da prerrogativa objeto da impetração -, uma vez transitada em julgado a decisão que julgou procedente o mandado de injunção -, seus efeitos poderão ser estendidos aos casos análogos por decisão monocrática do relator. ${ }^{35}$

\section{CONSIDERAÇÕES FINAIS}

Tradicionalmente, a doutrina tem abordado a temática da Teoria Geral do Direito Processual Coletivo de forma parcial, ou seja, limitada aos procedimentos civis, trabalhistas, eleitorais e administrativos.

O presente estudo pretende atentar para a necessidade de unificação, em uma só disciplina, da abordagem epistemológica do Direito Processual Coletivo (Penal e Não Penal).

Ora, a Ciência do Direito Processual Coletivo se desenvolveu sem que se buscasse a formação de uma estrutura uniforme de aplicação do Direito (epistemologia do Direito Processual Coletivo).

Contudo, a Teoria Geral do Direito Processual Coletivo deve ser vislumbrada enquanto disciplina jurídica com viés epistemológico, ramo da Filosofia do Direito Processual Coletivo, voltada à elaboração e à articulação de conceitos jurídicos fundamentais processuais coletivos (v.g., procedimento coletivo, coisa julgada coletiva, defesa coletiva, tutela jurisdicional coletiva, dentre outros).

Não se pode, portanto, confundir a Teoria Geral do Direito Processual Coletivo com a ideia de um "Direito Processual Unificado" (Não Penal e Penal), visto que o produto da Filosofia do Direito Processual Coletivo (ou seja, a Teoria Geral do Direito Processual

\footnotetext{
${ }^{35}$ Vejamos: Art. $9^{\circ}$ A decisão terá eficácia subjetiva limitada às partes e produzirá efeitos até o advento da norma regulamentadora. $\S 1$ o Poderá ser conferida eficácia ultra partes ou erga omnes à decisão, quando isso for inerente ou indispensável ao exercício do direito, da liberdade ou da prerrogativa objeto da impetração. $\$ 2^{\underline{o}}$ Transitada em julgado a decisão, seus efeitos poderão ser estendidos aos casos análogos por decisão monocrática do relator.
} 
Coletivo) não é a mesma coisa que um conjunto de normas jurídicas processuais (ou seja, o Direito Processual Coletivo).

Em consequência, à classificação tradicional do Direito Processual Coletivo (comum e especial), entendemos que deve ser acrescentado o viés penal, muitas vezes ignorado pela doutrina, permitindo que a Teoria Geral do Direito Processual Coletivo seja responsável pela coesão e coerência de caráter metodológico e científico, condensando normas e institutos penais e não penais do Direito Processual Coletivo.

Em suma, como só existe sentido na existência do processo se voltada para a busca pela pacificação social, a construção da Teoria Geral do Direito Processual Coletivo deve pensar de forma unificada a solução do conflito nas suas mais diversas vertentes, de modo a buscar a efetividade na aplicação de normas voltadas para a tutela de interesses de toda a sociedade.

\section{REFERÊECIAS:}

ALMEIDA, Gregório Assagra de. Direito Processual coletivo brasileiro. São Paulo: Saraiva, 2003.

ALMEIDA; Gregório Assagra de. COSTA, Rafael de Oliveira. Direito processual penal coletivo - A Tutela Penal dos Bens Jurídicos Coletivos: Direitos ou Interesses Difusos, Coletivos e Individuais Homogêneos. Belo Horizonte: D’Plácido, 2019.

ANDRADE, Adriano; MASSON, Cleber; ANDRADE, Landolfo. Interesses difusos e coletivos esquematizado. São Paulo: Método, 2011.

ARENHART, Sérgio Cruz. Perfis da tutela inibitória coletiva. São Paulo: RT, 2003.

BERIZONCE, Roberto O. Efectivo acceso a la justicia: prólogo de Mauro Cappelletti. La Plata. Librería Editora Platense, 1997.

CAPPELlETTI, Mauro; GARTH, Bryant. Acesso à justiça. Tradução de Ellen Gracie Northfleet. Porto Alegre: Sergio Antonio Fabris Editor, 1988.

CINTRA, Antonio Carlos de Araújo; DINAMARCO, Cândido Rangel; GRINOVER, Ada Pellegrini. Teoria geral do processo. 21. ed., rev. e atual. São Paulo: Malheiros Editores, 2005. 
COSTA, Rafael de Oliveira; MORAES, Alexandre Rocha Almeida de. O Processo Coletivo: primeiras impressões para a construção de uma nova dogmática processual. In: Revista Brasileira de Direito Processual Penal, v. 5, p. 1609 e seguintes, 2019.

DIDIER JR., Fredie; BRAGA, Paula Sarno; OLIVEIRA, Rafael. Curso de Direito Processual Civil. $7^{\mathrm{a}}$ ed. Salvador: JusPodivm, 2007. v. 2.

GAJARDONI, Fernando da Fonseca. Direitos difusos e coletivos I. São Paulo: Saraiva, 2012.

GIDI, Antonio. Rumo a um código de processo civil coletivo. Rio de Janeiro: Forense, 2008.

GIDI, Antonio; MC-GREGOR, Eduardo Ferrer (coords.). La tutela de los derechos difusos, colectivos e individuales homogéneos: hacia un código modelo para iberoamérica. México: Porrúa, 2003.

GRINOVER, Ada Pellegrini. Código Brasileiro de Defesa do Consumidor. $6^{\mathrm{a}}$ ed. Rio de Janeiro: Forense Universitária, 1999.

GRINOVER, Ada Pellegrini. Rumo a um Código Brasileiro de Processos Coletivos. MAZZEI, Rodrigo e NOLASCO, Rita Dias (Coordenadores). Processo Civil Coletivo. São Paulo: Quartier Latin, 2005.

LEAL, Márcio Flávio Mafra. Ações coletivas: história, teoria e prática. Porto Alegre: Sérgio Antonio Fabris Editor, 1998.

LEONEL, Ricardo de Barros. Manual do processo coletivo. São Paulo: RT, 2002.

MARINONI, Luiz Guilherme. Teoria geral do processo. São Paulo: RT, 2006.

MAZZILLI, Hugo Nigro. A defesa dos interesses difusos em juízo. 15 a ed. São Paulo: Saraiva, 2002.

MILARÉ, Edis. Ação Civil Pública - Lei 7.347/1985: reminiscência e reflexões após dez anos de aplicação. São Paulo, RT, 1995.

MIRANDA, Francisco Cavalcanti Pontes de. Comentários ao Código de Processo Civil. Rio de Janeiro: Forense, 1974. v. 9.

MOREIRA, José Carlos Barbosa. A ação popular do direito brasileiro como instrumento de tutela jurisdicional dos chamados interesses difusos. Temas de Direito Processual Civil. São Paulo: Saraiva, 1977.

NEVES, Daniel Amorim Assumpção. Manual de processo coletivo. 3. ed. Salvador: Ed. JusPodivm, 2016. 
Revista Eletrônica de Direito Processual - REDP.

Rio de Janeiro. Ano 16. Volume 23. Número 1. Janeiro a Abril de 2022

Periódico Quadrimestral da Pós-Graduação Stricto Sensu em Direito Processual da UERJ

Patrono: José Carlos Barbosa Moreira (in mem.). ISSN 1982-7636. pp. 1142-1159

www.redp.uerj.br

VITORELLI, Edilson. Levando os conceitos a sério: processo estrutural, processo coletivo, processo estratégico e suas diferenças. Revista de Processo, São Paulo, Ano 43, n. 284, p.333-369, out. 2018.

ZAVASCKI, Teori Albino. Processo Coletivo: Tutela de Direitos Coletivos e Tutela Coletiva de Direitos. São Paulo: Editora Revista dos Tribunais, 2006. 